\title{
PENGARUH LAYANAN INFORMASI DAN BIMBINGAN PRIBADI TERHADAP KEDISIPLINAN SISWA KELAS XII MA COKROAMINOTO WANADADI BANJARNEGARA TAHUN AJARAN 2014/2015
}

\author{
Ika Ernawati \\ Program Studi Bimbingan dan Konseling \\ Fakultas Keguruan dan Ilmu Pendidikan \\ Universitas PGRI Yogyakarta \\ E-mail: ikaerna60@yahoo.com
}

\begin{abstract}
Abstrak
Penelitian bertujuan untuk mengetahui 1) pengaruh layanan informasi terhadap kedisiplinan siswa, 2) pengaruh bimbingan pribadi terhadap kedisiplinan siswa, 3) pengaruh layanan informasi dan bimbingan pribadi terhadap kedisiplinan siswa kelas XII MA Cokroaminoto Wanadadi Banjarnegara Tahun 2014/2015. Populasi dalam penelitian ini seluruh siswa kelas XII MA Cokroaminoto Wanadadi yang berjumlah 83 siswa. Metode pengumpulan data menggunakan angket tertutup. Analisis data untuk hipotesis 1 dan hipotesis 2 menggunakan statistik korelasi product moment, untuk hipotesis 3 menggunakan rumus regresi ganda. Hasil penelitian bahwa 1) Ada pengaruh yang positif dan signifikan layanan informasi terhadap kedisiplinan siswa ( $\mathrm{xx} 1 \mathrm{y}=0,566$ dengan $\mathrm{p}=0,000$ ) artinya semakin baik layanan informasi yang diberikan kepada siswa akan mempengaruhi peningkatan kedisiplinan siswa, 2) Ada pengaruh yang positif dan signifikan bimbingan pribadi terhadap kedisiplinan siswa $(r \times 2 y=0,491$ dengan $p=0,000)$, 3) ada pengaruh yang positif layanan informasi dan bimbingan pribadi terhadap kedisiplinan siswa (Freg $=13,483$ dan nilai $\mathrm{p}=0,000)$.
\end{abstract}

Kata kunci : layanan informasi, bimbingan pribadi, kedisiplinan siswa

\begin{abstract}
The study aims to determine 1) the effect of information services on student discipline, 2) effect on the discipline of students personal guidance, 3) the effect of information services and personal counseling to discipline students of class XII MA Cokroaminoto Wanadadi Banjarnegara Year 2014/2015. The population in this study all students of class XII MA Tjokroaminoto Wanadadi totaling 83 students. Methods of data collection using the questionnaire enclosed. Data analysis for hypothesis 1 and hypothesis 2 using the product moment correlation statistic, for the third hypothesis using multiple regression formula. The results of the research that 1) There is a positive influence and significant information service to the discipline of students ( $r x 1 y=0.566, p=0.000)$ means the better the information services provided to students will affect the improvement of discipline of students, 2) There is a positive influence and significant personal guidance to discipline students ( $r \times 2 y=0.491, p=0.000), 3)$ there is a positive influence service information and personal guidance to discipline students (Freg $=13.483$ and $p=0.000$ ).

Key words: information services, personal guidance, discipline students
\end{abstract}

\section{Info Artikel}

Diterima Desember 2016, disetujui Desember 2016, diterbitkan Desember 2016 


\section{PENDAHULUAN}

Pendidikan merupakan proses pembentukan kepribadian manusia. Pendidikan pada umumnya bertujuan untuk membentuk manusia yang bermoral dan berilmu. Berbicara masalah pendidikan, menyangkut pula masalah tentang lingkungan pendidikan, yang dikenal dengan tripusat pendidikan, yaitu lingkungan keluarga, lingkungan sekolah dan masyarakat. Dari ketiga lingkungan tersebut yang paling berpengaruh dalam pemberian informasi dan pelayanan pembelajaran adalah lingkungan sekolah.

Fenomena yang terjadi di MA Cokroaminoto, tentang layanan informasi dalam bimbingan pribadi, ditunjukkan pada kedisiplinan siswa yang masih rendah. Berdasarkan kondisi tersebut guru BK sebagai pelaksana layanan informasi bimbingan pribadi yang secara rutin di ruang kelas telah dilaksanakan, namun belum optimal. Hal ini dapat diketahui pada saat penulis melakukan observasi awal, melalui observasi diperoleh data:

1. Jumlah guru BK terdiri dari 1 orang.

2. Ruangan bimbingan dan konseling terdiri dari ruang konseling individual dan ruang kerja guru BK.

Kedisiplinan merupakan suatu sikap, perilaku, dan perbuatan yang sesuai dengan organisasi baik tertulis maupun tidak tertulis. Kedisiplinan merupakan suatu kepatuhan atau kesediaan untuk mematuhi peraturan- peraturan yang berlaku. Kepatuhan disini bukan berarti hanya karena adanya tekanan-tekanan dari luar, melainkan kepatuhan yang didasari oleh adanya kesadaran tentang nilai dan pentingnya peraturan tersebut.

Melihat latar belakang masalah seperti di atas, peneliti tertarik untuk melakukan penelitian tentang Pengaruh Layanan Informasi Dan Bimbingan Pribadi Terhadap Kedisiplinan Siswa Kelas XII MA Cokroaminoto Wanadadi Banjarnegara Tahun Ajaran 2014/2015.

\section{TINJAUAN PUSTAKA}

\section{Pengertian Layanan Informasi}

Menurut Hallen, dalam Zainal Abidin dan Alief (2010:40), berpendapat layanan informasi ialah layanan bimbingan dan konseling yang memungkinkan klien menerima dan memahami berbagai informasi (informasi pendidikan, jabatan, karir) yang dapat dipergunakan sebagai bahan pertimbangan dan pengambilan keputusan demi kepentingan individu klien.

\section{Tujuan Layanan Informasi}

Menurut Budi Purwoko (2008:52) tujuan yang ingin dicapai dengan penyajian informasi adalah sebagai berikut:

1) Para siswa dapat mengorientasikan dirinya kepada informasi yang diperolehnya terutama untuk kehidupannya, baik semasa masih sekolah maupun setelah menamatkan sekolah. 
2) Para siswa mengetahui sumbersumber informasi yang diperlukan.

3) Para siswa dapat menggunakan kegiatan kelompok sebagai sarana memperoleh informasi.

4) Para siswa dapat memilih dengan tepat kesempatan-kesempatan yang ada dalam lingkungannya sesuai dengan minat dan kemampuannya.

\section{Fungsi Layanan Informasi}

Menurut Zainal Abidin \& Alief (2010:41) yang menjadi fungsi utama layanan informasi adalah fungsi pemahaman dan pencegahan.

1) Fungsi Pemahaman yaitu dengan adanya individu mendapatkan layanan informasi akan memberikan dan meningkatkan pemahaman diri terhadap berbagai persoalan hidup sebagai individu, anggota keluarga, maupun anggota masyarakat, sehingga mampu menempatkan posisinya pada alur yang lebih tepat.

2) Fungsi Pencegahan yaitu dengan layanan informasi tadi individu menjadi memiliki pemahaman yang lebih terhadap berbagai hal tentang kehidupan, sehingga dirinya dapat terhindar dari berpola hidup yang tidak benar, penyusunan program hidup yang tidak relevan serta terhindar dari pengambilan keputusan yang tidak tepat.

\section{Jenis-jenis Layanan Informasi}

Menurut Prayitno \&Erman Amti (2004:261-268) pada dasarnya jenis dan jumlah informasi tidak terbatas. Namun, khusunya dalam rangka pelayanan bimbingan dan konseling, hanya akan dibicarakan tiga jenis informasi, yaitu :

1) Informasi pendidikan,

Infprmasi pendidikan meliputi : (a)

pemilihan program studi, (b) pemilihan sekolah fakultas dan jurusannya, (c) penyesuaian diri dengan program studi, (d) penyesuaian diri dengan suasana belajar, dan (e) putus sekolah. Mereka membutuhkan adanya keterangan atau informasi untuk dapat membuat pilihan dan keputusan yang bijaksana.

2) Informasi jabatan

Informasi jabatan ini penting diberikan kepada para siswa, agar mereka memiliki pengetahuan dan pemahaman terhadap jenis pekerjaan sesuai dengan jurusan masing-masing.

3) Informasi sosial budaya

Informasi sosial budaya meliputi, macam-macam suku bangsa, adat istiadat, agama dan kepercayaan, bahasa, potensi-potensi daerah dan kekhususan masyarakat atau daerah tertentu.

\section{Dasar-Dasar Pemberian Layanan Informasi}

Menurut Prayitno \& Erman Amti (2004:260-261) ada empat alasan utama mengapa layanan informasi perlu diselenggarakan.

1) Membekali individu dengan berbagai pengetahuan tentang lingkungan yang diperlukan, guna 
memecahkan masalah yang dihadapi berkenaan dengan lingkungan sekitar, pendidikan, jabatan maupun sosial budaya yang melingkari pengambilan keputusan dan hajat hidupnya.

2) Memungkinkan individu dapat membelajarkan diri menentukan arah hidupnya kemananpun yang ingin dituju. Artinya dengan informasi yang jelas sehingga mereka tahu apa yang harus diberitahukan dan bagaimana harus bertindak kreatif, motivatif, dan dinamis.

3) Setiap individu adalah unik, artinya dengan keunikan masingmasing individu akan mewujudkan pola pengambilan keputusan hidup yang beragam, begitu pula dalam cara bertindak. Dengan keanekaragaman tersebut diharapkan agar dapat menciptakan dinamika perkembangan individu dan masyarakat secara potensial dan positif.

4) Masa depan adalah layanan informasi dan telah menjadi kebutuhan mendasar bagi umat manusia, maka bagi individu yang tidak mengindahkanya akan tertinggal jauh dilandasan kehidupan dan kehilangan masa depanya.

\section{Metode Layanan Informasi}

Menurut Prayitno \& Erman Amti (2004:269-271) Pemberian informasi kepada siswa dapat dilakukan dengan berbagai cara yakni :1) ceramah, 2) diskusi, 3) karya wisata, 4) buku panduan, dan 5) konferensi karir.

\section{Pengertian Bimbingan Pribadi}

Menurut Juntika (2006:16) menjelaskan, bahwa bimbingan pribadi adalah bimbingan yang diarahkan untuk memantapkan kepribadian dan mengembangkan kemampuan individu dalam menangani masalah dirinya.

Sedangkan menurut Dewa Ketut Sukardi (2008:55) Bimbingan pribadi adalah upaya untuk membantu siswa menemukan dan mengembangkan pribadi yang beriman dan bertakwa kepada Tuhan Yang Maha Esa, mantap dan mandiri, serta sehat jasmani dan rohani.

Berdasarkan pendapat di atas dalam mendefinisikan istilah bimbingan pribadi, para ahli bidang bimbingan dan konseling memberikan pengertian yang berbeda-beda.

\section{Tujuan Bimbingan Pribadi}

Tujuan layanan bimbingan pribadi menurut Damayanti (2014:10) antara lain:

1) Memiliki sikap respek terhadap diri sendiri.

2) Dapat mengelola stress.

3) Memahami perasaan diri dan mampu mengekspresikannya secara wajar.

4) Memiliki kemampuan memecahkan masalah.

5) Memiliki rasa percaya diri.

6) Memiliki mental yang sehat. 


\section{Pokok-Pokok Bidang Bimbingan Pribadi}

Menurut Dewa Ketut Sukardi (2008:54) pokok-pokok bimbingan pribadi meliputi:

1) Pemantapan sikap dan kebiasaan serta pengembangan wawasan dalam beriman dan bertakwa terhadap Tuhan Yang Maha Esa.

2) Pemantapan pemahaman tentang kekuatan diri dan pengembangannya untuk kegiatan-kegiatan yang kreatif dan produktif, baik dalam kehidupan sehari-hari maupun untuk peranannya dimasa depan.

3) Pemantapan pemahaman tentang bakat dan minat pribadi serta penyaluran dan pengembangannya melalui kegiatan-kegiatan yang kreatif dan produktif.

4) Pemantapan pemahaman tentang kelemahan diri dan usaha-usaha penanggulangannya.

5) Pemantapan kemampuan mengambil keputusan.

6) Pemantapan kemampuan mengarahkan diri sesuai dengan keputusan yang telah diambilnya.

7) Pemantapan dalam perencanaan dan penyelenggaraan hidup sehat, baik secara rohani maupun jasmani.

\section{Macam-Macam Bimbingan Pribadi}

Menurut Rudi Mulyatiningsih (2004:3-39) adapun macam-macam bimbingan pribadi meliputi :

1) Cara menyesuaikan diri dengan perkembangan fisik dan psikis yang terjadi pada masa remaja.
2) Cara mengendalikan dan mengalahkan emosi.

3) Cara mengembangkan sifat positif.

4) Cara menghindari prasangka dan menghindari akibatnya.

5) Cara menghindari rendah diri.

\section{Pengertian Kedisiplinan}

Disiplin adalah sebagai proses belajar mengajar yang mengarah kepada ketertiban dan pengendalian diri. Menurut Wyckoff yang dikutip oleh Suryadi tahun (2007:75). Disiplin menurut Djamarah adalah "suatu tata tertib yang dapat mengatur tatanan kehidupan pribadi dan kelompok" (Djamarah, Prestasi Belajar dan Kompetensi Guru (Surabaya: Usaha Nasional, 2002:12). Kedisiplinan mempunyai peranan penting dalam mencapai tujuan pendidikan.Berkualitas atau tidaknya belajar siswasangat dipengaruhi oleh paktor yang paling pokok yaitu kedispilan, disamping faktor lingkungan, baik keluarga, sekolah, kedisiplinan serta bakat siswa itu sendiri. Menurut Kamus Bahasa Indonesia (2007:286), menyatakan bahwa disiplin adalah:

1) Tata tertib (di sekolah, di kantor, kemiliteran, dan sebagainya).

2) Ketaatan (kepatuhan) pada peraturan tata tertib.

3) Bidang studi yang memiliki objek dan sistem tertentu.

Kedisiplinan adalah suatu kondisi yang tercipta dan terbentuk melalui proses dari serangkaian perilaku yang menunjukan nilai-nilai ketaatan, kepatuhan, kesetiaan, 
keteraturan, dan atau ketertiban. Karena sudah menyatu dengannya, maka sikap atau perbuatan yang dilakukan bukan lagi atau sama sekali tidak dirasakan sebagai beban, bahkan sebaliknya akan membebani dirinya bilamana ia tidak berbuat sebagaimana lazimnya.

\section{Fungsi Kedisiplinan}

Fungsi kedisiplinan menurut Tu'u (2004:38) sebagai berikut: 1) menata kehidupan bersama,2) membangun kepribadian, 3) melatih kepribadian, 4) pemaksaan, 5) hukuman, menciptakan lingkungan yang kondusif. Kedisiplinan berfungsi mendukung terlaksananya proses dan kegiatan pendidikan agar berjalan lancar dan memberi pengaruh bagi terciptanya sekolah sebagai lingkungan pendidikan yang kondusif bagi kegiatan pembelajaran.

\section{Tujuan Kedisiplinan}

Maman Rachman (2004:35) mengemukakan bahwa tujuan disiplin sekolah adalah:

1) Memberi dukungan bagi terciptanya perilaku yang tidak menyimpang.

2) Mendorong siswa melakukan yang baik dan benar.

3) Membantu siswa memahami dan menyesuaikan diri dengan tuntutan lingkungannya dan menjauhi melakukan hal-hal yang dilarang oleh sekolah.

4) Siswa belajar hidup dengan kebiasaan-kebiasaan yang baik dan bermanfaat baginya serta lingkungannya.

5) Kedisiplinan diterapkan tanpa menunjukkan kelemahan, tanpa menunjukkan amarah dan kebencian, kalau perlu dengan kelembutan agar para pelanggar kedisiplinan menyadari bahwa disiplin itu diterapkan demi kebaikan dan kemajuan dirinya.

6) Kedisiplinan mesti diterapkan secara tegas, adil dan konsisten.

Faktor Yang Mempengaruhi Kedisiplinan

Menurut Ekosiswoyo dan Rachman (2000:100-105), faktorfaktor yang mempengaruhi kedisiplinan, antara lain:

Dari sekolah, contohnya:

1) Tipe kepemimpinan guru atau sekolah yang otoriter yang senantiasa mendiktekan kehendaknya tanpa memperhatikan kedaulatan siswa..

2) Guru yang membiarkan siswa berbuat salah, lebih mementingkan pelajaran dari pada siswanya.

3) Lingkungan sekolah seperti: harihari pertama dan hari-hari akhir sekolah (akan libur atau sesudah libur), pergantian pelajaran, pergantian guru, jadwal yang kaku atau jadwal aktivitas sekolah yang kurang cermat, suasana yang gaduh, dll.

\section{Cara Terbentuknya Kedisiplinan}

Menurut lembaga ketahanan nasional (2004:15), kedisiplinan dapat terjadi dengan cara: 
1) Disiplin tidak terjadi dengan sendirinya, melainkan harus ditumbuhkan, dikembangkan dan diterapkan dalam semua aspek menerapkan sanksi serta dengan bentuk ganjaran dan hukuman.

2) Disiplin seseorang adalah produk sosialisasi sebagai hasil interaksi dengan lingkungannya, terutama lingkungan sosial. Oleh karena itu, pembentukan disiplin tunduk pada kaidah-kaidah proses belajar.

3) Dalam membentuk disiplin, ada pihak yang memiliki kekuasaan lebih besar, sehingga mampu mempengaruhi tingkah laku pihak lain kearah tingkah laku yang diinginkannya.

\section{Aspek-Aspek Kedisiplinan}

Menurut

Prijodarminto

(2004:31), disiplin memiliki (tiga) aspek, ketiga aspek tersebut adalah sebagai berikut:

1) Sikap mental (mental attitude) yang merupakan sikap taat dan tertib sebagai hasil atau pengembangan dari latihan, pengendalian pikiran dan pengendalian watak.

2) Pemahaman yang baik mengenai sistem peraturan perilaku, norma, kriteria, dan standar yang demikian rupa, sehingga pamahaman tersebut menumbuhkan pengertian yang mendalam atau kesadaran, bahwa ketaatan akan aturan.

3) Sikap kelakuan yang secara wajar menunjukkan kesungguhan hati, untuk mentaati segala hal secara cermat dan tertib.

\section{Macam-Macam Kedisiplinan}

Berdasarkan ruang lingkup berlakunya ketentuan atau peraturan yang harus dipatuhi, disiplin dapat dibedakan sebagai berikut:

1. Disiplin diri

Disiplin diri (disiplin pribadi atau swadisiplin), yaitu apabila peraturan-peraturan atau ketentuan-ketentuan itu hanya berlaku bagi diri seseorang. Misalnya, disiplin belajar, disiplin bekerja, disiplin beribadah.

2. Disiplin sosial

Disiplin sosial adalah apabila ketentuan-ketentuan atau peraturan-peraturan itu harus dipatuhi oleh orang banyak atau masarakat. Misalnya, disiplin lalu lintas, dan disiplin menghadiri rapat.

3. Disiplin nasional

Disiplin nasional adalah apabila peraturan-peraturan atau ketentuan-ketentuan itu merupakan tata laku bangsa atau norma kehidupan berbangsa dan bernegara yang harus dipatuhi oleh seluruh rakyat. Misalnya, disiplin membayar pajak dan disiplin mengikuti upacara bendera (asy mas'udi, pendidikan pancasila dan kewarganegaraan (Yogyakarta : PT Tiga Serangkai, 2000:88-89).

\section{HIPOTESIS}

1. Ada pengaruh positif layanan informsi terhadap kedisiplinan 
siswa kelas XII MA Cokroaminoto Wanadadi Banjarnegara Tahun Ajaran 2014/2015.

2. Ada pengaruh positif bimbingan pribadi terhadap kedisiplinan siswa kelas XII MA Cokroaminoto Wanadadi Banjarnegara Tahun Ajaran 2014/2015.

3. Ada pengaruh positif layanan informasi dan bimbingan pribadi terhadap kedisiplinan siswa kelas XII MA Cokroaminoto Wanadadi Banjarnegara Tahun Ajaran 2014/2015.

\section{TEKHNIK PENELITIAN}

Penelitian ini akan dilaksanakan di MA Cokroaminoto Wanadadi Banjarnegara Tahun Pelajaran 2014/2015. Penelitian ini dilakukan dimulai dari bulan Agustus sampai dengan bulan September tahun 2014. Penelitian ini merupakan penelitian populasi dengan populasi penelitian adalah seluruh siswa kelas XII MA Cokroaminoto Wanadadi Tahun Pelajaran 2014/2015, yang berjumlah 83 orang siswa. Metode pengumpulan data menggunakan angket langsung tertutup, yang terdiri atas 3 angket, masing-masing angket terdiri dari 20 butir pertanyaan/pernyataan.Sebelum digunakan untuk mengambil data penelitian, angket tersebut diujicobakan terlebih dahulu kepada 20 siswa SMA Muhammadiyah Wanadadi.Berdasarkan hasil perhitungan dengan menggunakan program SPS 2000 Sutrisno Hadi dan Yuni Pamardiningsih maka dapat disimpulkan bahwa angket layanan informasi yang berjumlah 20 butir terdapat 2 (dua) butir yang gugur yaitu no. 14 dan no. 19 , angket bimbingan pribadi dengan jumlah 20 butir terdapat 1 (satu) butir yang gugur yaitu no. 20.Sedangkan angket kedisiplinan siswa yang berjumlah 20 butir terdapat 2 (dua) butir yang gugur yaitu no. 7 dan no. 19 .

Berdasarkan hasil uji coba reliabilitas instrumen dengan menggunakan komputerisasi program SPS 2000 Sutrisno Hadi dan Yuni Pamardiningsih menunjukkan bahwa instrumen layanan informasi diperoleh koefisien reliabilitas Alpha (rii) = 0,905 dengan peluang galat $0,000<$ 0,05 . Jadi instrumen layanan informasi mempunyai reliabilitas yang tinggi. Instrumen bimbingan pribadi diperoleh koefisien reliabilitas Alpha (rii) $=0,898$ dengan peluang galat $0,000<0,05$. Jadi instrumen bimbingan pribadi mempunyai reliabilitas yang tinggi. Instrumen kedisiplinan siswa diperoleh koefisien reliabilitas Alpha (rii) $=$ 0,917 dengan peluang galat $0,000<$ 0,05. Jadi instrumen kedisiplinan siswa mempunyai reliabilitas yang tinggi.

Untuk menganalisis data yang terkumpul digunakan teknik analisis korelasi product moment dan regresi ganda dua prediktor.

\section{HASIL PENELITIAN DAN PEMBAHASAN}


Data tentang layanan informasi diperoleh melalui angket yang bersifat tertutup dengan jumlah item sebanyak 18 butir. Skor yang digunakan dalam angket tersebut 1-4 sehingga berdasarkan skor tersebut maka variabel layanan informasi memiliki rentang skor 18-72. Berdasar data induk yang diperoleh dari responden pada penelitian ini diperoleh skor terendah 39 dan skor tertinggi 63 . Data layanan informasi meliputi $33,73 \%$ berada pada kategori tinggi, $49,40 \%$ berada pada kategori sedang dan $16,87 \%$ berada pada kategori rendah. Maka dapat dikatakan bahwa data layanan informasi siswa Kelas XII MA Cokroaminoto Wanadadi Banjarnegara Tahun Pelajaran 2014/2015 cenderung sedang.

Data tentang bimbingan pribadi diperoleh melalui angket yang bersifat tertutup dengan jumlah item sebanyak 19 butir. Skor yang digunakan dalam angket tersebut 1-4 sehingga berdasarkan skor tersebut maka variabel bimbingan pribadi memiliki rentang skor 19-76. Berdasar data induk yang diperoleh dari responden pada penelitian ini diperoleh skor terendah 44 dan skor tertinggi 71 . Data bimbingan pribadi meliputi $34,94 \%$ berada pada kategori tinggi, $54,22 \%$ berada pada kategori sedang dan $10,84 \%$ berada pada kategori rendah. Maka dapat dikatakan bahwa data bimbingan pribadi siswa Kelas XII MA Cokroaminoto Wanadadi Banjarnegara Tahun Pelajaran 2014/2015 cenderung sedang.
Data tentang kedisiplinan siswa diperoleh melalui angket yang bersifat tertutup dengan jumlah item sebanyak 18 butir. Skor yang digunakan dalam angket tersebut 1-4 sehingga berdasarkan skor tersebut maka variabel kedisiplinan siswa memiliki rentang skor 18-72. Berdasar data induk yang diperoleh dari responden pada penelitian ini diperoleh skor terendah 34 dan skor tertinggi 72 . Dapat dinyatakan bahwa data kedisiplinan siswa meliputi 31,33\% berada pada kategori tinggi, 57,83\% berada pada kategori sedang dan $10,84 \%$ berada pada kategori rendah. Maka dapat dikatakan bahwa data kedisiplinan siswa Kelas XII MA Cokroaminoto Wanadadi Banjarnegara Tahun Pelajaran 2014/2015 cenderung sedang.

Untuk analisis data digunakan teknik analisis lorelasi product moment danteknik analisis regresi ganda.

1. Berdasarkan penghitungan menggunakan jasa komputer SPS Edisi Sutrisno Hadi dan Yuni Pamardiningsih Universitas Gajah Mada Yogyakarta Indonesia Hak Cipta 2001 didapat harga koefisien korelasi pengaruh layanan informasi $\left(\mathrm{X}_{1}\right)$ dengan kedisiplinan siswa $(Y)$ sebesar 0,566 dan nilai $p$ $=0,000$. Hal ini menunjukkan bahwa nilai $\mathrm{p}<0,01$ yang berarti ada pengaruh yang positif dan signifikan layanan informasi terhadap kedisiplinan siswa. 
2.

3. Tabel 1.

4. Tabel Interkorelasi

5.

\begin{tabular}{|c|c|c|c|}
\hline 6. r & x1 & $\mathrm{x} 2$ & $\mathrm{y}$ \\
\hline 8. $\mathrm{x} 1$ & 1.000 & 0.308 & 0.566 \\
\hline 9. $\mathrm{p}$ & 0.000 & 0.005 & 0.000 \\
\hline 10. $\mathrm{x} 2$ & 0.308 & 1.000 & 0.491 \\
\hline 11. $\mathrm{p}$ & 0.005 & 0.000 & 0.000 \\
\hline 12. $\mathrm{y}$ & 0.566 & 0.491 & 1.000 \\
\hline 13. $\mathrm{p}$ & 0.000 & 0.000 & 0.000 \\
\hline
\end{tabular}

15. $\mathrm{p}=$ dua-ekor.

16.

17. Berdasarkan analisis dengan bantuan jasa komputer SPS Edisi Sutrisno Hadi dan Yuni Pamardiningsih Universitas Gajah Mada Yogyakarta Indonesia Hak Cipta 2001 didapat harga koefisien korelasi pengaruh bimbingan pribadi (X2) dengan kedisiplinan siswa (Y) sebesar 0,491 dan nilai $\mathrm{p}$ $=0,000$. Hal ini menunjukkan bahwa nilai $\mathrm{p}<0,01$ yang berarti ada pengaruh yang positif dan signifikan bimbingan pribadi terhadap kedisiplinan siswa.

18. Berdasarkan analisis dengan bantuan jasa komputer SPS Edisi Sutrisno Hadi dan Yuni Pamardiningsih Universitas Gajah Mada Yogyakarta Indonesia Hak Cipta 2001diperoleh harga Freg = 30,346 dan nilai $\mathrm{p}=0,000$. Hal ini menunjukkan bahwa nilai $\mathrm{p}<0,01$ yang berarti layanan informasi dan bimbingan pribadi secara bersamasama mempengaruhi kedisiplinan siswa.

19.

20. Tabel 2.

21. Table Rangkuman Anareg

22.

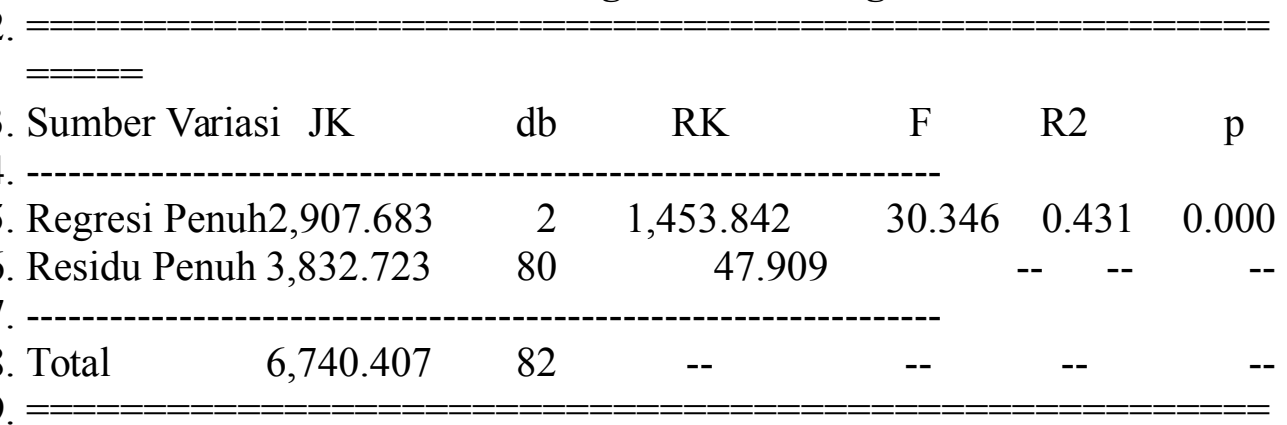

30. 
31. Sedangkan bobot sumbangan untuk masing-masing variabel bebas terhadap variabel terikat

32. pada penelitian ini dapat dilihat pada tabel berikut:

33. Tabel 3.

34. Tabel Perbandingan Bobot Prediktor

35.

36.

37. VariabelKorelasi Lugas

38. $\mathrm{X}$ r xy

Korelasi Parsial

Bobot Sumbangan

\begin{tabular}{ll}
$\mathrm{p}$ \\
\hline 39.10 .566 & 0.000
\end{tabular}

$p$

rxy-sisa

39. $10.566 \quad 0.000$

Relatif SR\%

Efektif SE\%

40. $60.072 \quad 25.914$

$\begin{array}{llllll}41.2 & 0.491 & 0.000 & 0.404 & 0.000 & 39.928\end{array}$

0.000

42.

43. Total --

100.00

17.224

44.

45 .

46.Berdasarkan tabel tersebut dapat diprediksi bahwa layanan informasi dan bimbingan pribadi mempunyai peranan dalam mempengaruhi peningkatan kedisiplinan siswa, terbukti kedua faktor tersebut mempunyai sumbangan efektif terhadap peningkatan kedisiplinan siswa sebesar $43,138 \%$.

\section{7.}

\section{KESIMPULAN}

49. Berdasarkan dari

analisis data dalam penelitian ini maka dapat ditarik kesimpulan sebagai berikut :

1. Layanan informasi berpengaruh positif dan signifikan terhadap kedisiplinan siswa kelas XII MA Cokroaminoto Wanadadi Banjarnegara tahun pelajaran 2014/2015.

2. Bimbingan pribadi berpengaruh positif dan signifikan terhadap kedisiplinan siswa Kelas XII MA Cokroaminoto Wanadadi Banjarnegara tahun pelajaran 2014/2015.

3. Layanan informasi dan bimbingan pribadi berpengaruh positif dan signifikan terhadap kedisiplinan siswa Kelas XII MA Cokroaminoto Wanadadi Banjarnegara tahun pelajaran 2014/2015.

4. Sumbangan efektif variabel layanan informasi dan bimbingan pribadi secara bersama-sama terhadap peningkatan kedisiplinan siswa sebesar 43,138\%.

\section{IMPLIKASI}

51. Layanan informasi mempunyai peranan yang penting dalam memberikan informasi yang tentang perilaku yang baik sehingga 
dapat meningkatkan kedisiplinan siswa untuk mendukung siswa untuk belajar secara tertib. Apabila layanan informasi yang diberikan pada siswa khususnya berkaitan dengan kedisiplinan, siswa akan lebih memahami dan mengerti tentang perilaku yang baik pada dirinya dan lingkungan sekitar. Maka akan meningkat kedisiplinan siswa dan tercapai prestasi belajar yang baik.

52. Bimbingan pribadi yang baik dan positif pada siswa dapat memberikan motivasi dan dukungan dalam perilaku sehari-hari di sekolah maupun di rumah. Dengan adanya bimbingan pribadi yang baik dan positif akan sangat potensial untuk menjalankan fungsi instrumental sebagai alat untuk mempengaruhi atau membujuk orang lain. Maka perilaku siswa akan menjadi baik dan dapat lebih bertanggung jawab dalam perilakunya. Bimbingan pribadi yang baik dan positif berperan dalam meningkatkan kedisiplinan siswa.

53.

\section{DAFTAR PUSTAKA}

55. Ahmad Juntika Nurihsan. H dan Akur Sudianto. 2006. Manajemen Bimbingan Dan Konseling di SMP. Jakarta : PT 56. Grasindo Anggota Ikapi.

$57 . \quad$ 2005. Manajemen Bimbingan Dan Konseling di SMP. Jakarta : PT Grasindo Anggota Ikapi.

58.

59. Asy Mas'udi. 2000 Pendidikan Pancasila Dan
60.

Kewarganegaraan. Yogyakarta: PT Tiga Serangkai.

61. Budi Purwoko. 2008. Organisasi Dan Managenen Bimbingan Konseling. Surabaya: Unesa University Press.

62.

63. Burhan Bungin. 2006. Metodologi Penelitian Kuantitatif. Jakarta : Kencana.

64.

65. Damayanti, Nidya. (2014). Buku Pintar Panduan Bimbingan Konseling. Yogyakarta: Araska.

66.

67. Dewa Ketut S. 2008. Pengantar Pelayanan Program BK Di Sekolah. Jakarta: Rineka Cipta.

68.

69. Direktorat Pendidikan Lanjutan Pertama. 2004. Pedoman Pelaksanaan Pelayanan Bimbingan Dan Konseling. Jakarta : Departemen Pendidikan Nasional.

70.

71. Djamarah. 2002. Prestasi Belajar Dan Kompetensi Guru. Surabaya: Usaha Nasional.

72.

73. Ekosiswoyo dan Rachman. 2000. Manajemen Kelas Semarang:IKIP Semarang Press.

74.

75. Jamal Ma'mur Asmani. 2010. Panduan Efektif Bimbingan Dan Konseling Di Sekolah. Yogyakarta: DIVA Press.

76.

$77 . \quad$ 2011. Tuntunan

Lengkap Metodologi Praktis

Penelitia Pendidikan. Penerbit Diva Press (Anggota IKAPI). 
79. Lemhannas. 2004. Disiplin Nasional. Jakarta: Balai Pustaka. 80.

81. Maman Rachman. 2004. Manajemen Kelas. Semarang:IKIP Semarang Press.

82.

83. Prayitno dan Erman Amti. 2004. Dasar-Dasar Bimbingan Konseling. Jakarta: Rineka Cipta.

84.

85. Prijodarminto. 2004. Disiplin Kiat Menuju Sukses. Jakarta: Pradnya Paramita.

86.

87. Rudi Mulyatiningsih. 2004. Bimbingan Pribadi, Sosial, Belajar Dan Karir. PT Grasindo, Jakarta.

88.

89. Sugiyono. 2011. Statistika Untuk Penelitian. Bandung: CV. Alfabeta.

90.

91. Suharsimi, Arikunto. 2010. Prosedur Penelitian. -Ed. Rev 2014. Jakarta: Rineka Cipta.
92.

93. Suryadi.

2007(http://KEPRIBADIAN >>

Pengertian Kepribadian

belajarpsikologi.com), diakses 12 april, 2014(online).

94.

95. Sutrisno Hadi dan Yuni Pamardiningsih. 2000. Seri Program Statistik (SPS). Yogyakarta : Universitas Gajah Mada Indonesia Hak Cipta 2001.

96.

97. Sutrisno Hadi. 2006. Metodologi Research. Yogyakarta: Andi Offset.

98.

99. Tulus Tu'u. 2004. Peran Disiplin Pada Perilaku Dan Prestasi Siswa. Jakarta Grasindo.

100.

101. Winkel W.S. dan Sri Hastuti. 2010. Bimbingan Dan Konseling. Yogyakarta : Media Abadi.

102. 